УДК [378.091.33:811.111]:(004+005.336.2)

DOI:

Тетяна Гурова, кандидат педагогічних наук, доцент кафедри англійської філології та методики викладання англійської мови Мелітопольського державного педагогічного університету імені Богдана Хмельницького Тетяна Рябуха, старший викладач кафедри англійської філологіi та методики викладання англійської мови

Мелітопольського державного педагогічного університету імені Богдана Хмельницького

Наталя Гостіщева, асистент кафедри англійської філологї та методики викладання англійської мови

Мелітопольського державного педагогічного університету імені Богдана Хмельницького

\title{
МЕДІАОСВІТНІ ТЕХНОЛОГІЇ ЯК ЗАСІБ ФОРМУВАННЯ АНГЛОМОВНОЇ КОМУНІКАТИВНОЇ КОМПЕТЕНТНОСТІ СТУДЕНТІВ-ФІЛОЛОГІВ
}

У статті висвітлено можливості медіа освітніх технологій для формування англомовноі комунікативної компетентності студентів-філологів. Проведено аналіз теоретичних праць вітчизняних та зарубіжних науковців, який свідчить, щзо формування комунікативної компетентності у сучасному інформаційному суспільстві неможливе без урахування потенційних можливостей медіа освітніх технологій. Зокрема, обтрунтовано необхідність введення ресурсів хмарних технологій у проиес вивчення англійськоі мови. Розкрито сутність та етапи роботи у безкоштовному веб-сервісі Google Classroom на заняттях $з$ курсу “Основна іноземна мова".

Ключові слова: медіа освітні технології; формування комунікативної компетентності; студентифілологи; практичні заняття з англійської мови.

Jim. 7.

Tetyana Hurova, Ph.D.(Pedagogy), Associate Professor of the English Philology and Methods of Teaching English Department Melitopol Bohdan Khmelnytskiy State Pedagogical University

Tetyana Ryabukha, Senior Lecturer of the

English Philology and Methods of Teaching English Department Melitopol Bohdan Khmelnytskiy State Pedagogical University Nataliya Hostishcheva, Assistant of the English Philology and Methods of Teaching English Department Melitopol Bohdan Khmelnitskiy State Pedagogical University

\section{MEDIA-EDUCATIONAL TECHNOLOGIES FOR FORMING ENGLISH COMMUNICATIVE COMPETENCE OF STUDENTS-PHILOLOGISTS}

The current state of philological education requires solving a number of tasks: the development of professional competence of students-philologists; general development of philological culture of future specialists; adjustment of the contents of the professional training of students of philological faculty through the introduction into the educational process of materials that prepares students for the preparation of international examinations; intensification and optimization of the process of teaching students of philology through the use of modern media technologies.

Formation of communicative competence of specialists-philologists is an important part of the development of their professional competence.

The establishment of a media education, cloud-based technologies in particular, in teaching English is becoming a natural phenomenon, taking into account the dependence of modern youth on the Internet, as well as on its integration with the technical progress. A specialist is capable of using technologies and information effectively in their work, have a new type of thinking, which gives them certain advantages in the labour market, so specialists are able to comprehend in new ways the problems they face in their professional activities.

In addition, the influence of cloud technologies in the development of foreign languages leads to solving such linguistic tasks: the enhancement of language learning motivation, the development of language skills and the ability to learn language comprehensively; increase of active students in language learning; forming skills in four types of speech activity and of course the formation of communicative competence.

Keywords: means of formation of English communicative competence; students-philologists; Google Classroom; cloud-based technologies. 


\section{МЕДІАОСВІТНІ ТЕХНОЛОГІЇ ЯК ЗАСІБ ФОРМУВАННЯ АНГЛОМОВНОӤ КОМУНІКАТИВНОӤ КОМПЕТЕНТНОСТІСТУДЕНТІВ-ФІЛОЛОГІВ}

увагу пошуку нових підходів до організації діяльності на практичних заняттях $з$ англійської мови. Саме тому викладачі англійської мови знаходяться у неперервному пошуку інноваційних ефективних методів навчання. Створення медіаосвітнього середовища у процесі навчання англійської мови стає природним явищем, враховуючи залежність сучасної молоді від Інтернет, смартфонів та комп'ютерів, а також їі інтерес до всього, що пов'язано 3 технічним прогресом. Це надає можливість наблизити академічну атмосферу вищої школи до реалій сучасного інформаційного суспільства, сприяє максимально повному задоволенню інформаційноосвітніх потреб суб'єктів навчальної діяльності, підвищує інтерес до навчання за посередництва та на матеріалі іншомовних медіа, сприяє формуванню комунікативної компетентності студентів-філологів.

Аналіз досліджень та публікацій. Запровадження компетентнісного підходу до побудови освітніх програм підготовки фахівців різних рівнів відбувається з огляду на прямування нашої країни до Болонського процесу. Це пояснює той факт, що поняття “компетентність” вважається однією 3 основних категорій студентоцентрованого навчання. Ідеї щодо обгрунтування і реалізації компетентнісного підходу в освіті можна знайти в роботах науковців: В. Антипової, О. Деркач, І. Зимньої, В. Козирєвої, Л. Лаптєвої, О. Маркової, Г. Селевко та ін. В цілому, цей термін можна тлумачити як інформованість, авторитетність або обізнаність.

У наукових джерелах можна зустріти достатню кількість робіт, присвячених проблемі якісної підготовки фахівців: Н. Вашуленко, К. ДурайНовакова, І. Зязюн, Л. Коваль, О. Комар, С. Литвиненко, Л. Хомич, I. Шапошникова та ін. Питання уточнення термінів “компетенція" і “компетентність" знайшли своє відображення в працях:Н. Бібік, Н. Свтуха, Я. Кічук, А. Кузьмінського, Н. Ничкало, О. Пометун, В. Сластьоніна та ін. Аналіз наукових досліджень в цій області показав, що вивченню основ і способів формування АККкомпетентності (англомовної комунікативної компетентності) майбутніх фахівців засобами медіа освітніх технологій в сфері філологічної освіти приділено недостатньо уваги.

Мета статті - висвітлити способи формування АКК компетентності (англомовної комунікативної компетентності) студентівфілологів на заняттях з англійської мови на прикладі використання хмарної технології Google Classroom i обгрунтувати доцільність застосування медіа освітніх технологій під час вивчення англійської мови.
Виклад основного матеріалу. Нагальним питанням сучасної методики викладання іноземних мов є потреба відбору актуального та цікавого для студентів навчального матеріалу та використання таких методів і прийомів навчання, які сприятимуть створенню на заняттях 3 іноземної мови іншомовного середовища та контексту для спілкування, що спонукатиме майбутніх фахівців до висловлення власної думки, дискусій, та виникнення в них стійкого інтересу до мовленнєвої діяльності. Зокрема, останніми роками у психолого-педагогічній літературі активно досліджуються питання впровадження медіаосвіти та їі технологій у навчально-виховний процес.

Ці технології є одним із способів реалізовувати заявлені навички студентів, розширювати межі їхньої інформаційно-комунікативної компетенції. Так, поступово вони стають системо угворюючим інструментом розвитку інформаційного простору. Завдяки цим технологіям реалізуються принципи, що лежать в основі системно-діяльнісного підходу. До них належать: виховання і розвиток особистості, що відповідають вимогам інформаційного суспільства, інноваційної економіки; перехід до технологій освіти, які націлені на досягнення соціально бажаного результату, особистісного і пізнавального розвитку тих, хто навчається; розвиток особистості того, хто навчається на основі засвоєння універсальних навчальних дій; визнання вирішальної ролі змісту освіти, способів організації освітньої діяльності та взаємодії учасників освітньої діяльності для досягнення особистісного, соціального i пізнавального розвитку студентів; врахування індивідуальних, вікових, психологічних і фізіологічних особливостей студентів, у зв'язку з різноманітністю організаційних форм, що забезпечують ріст творчого потенціалу, пізнавальних мотивів, збагачення форм взаємодії у пізнавальній діяльності; стабільність у досягненні запланованих результатів (особистісних, мета предметних і предметних), що є основою для самостійного успішного засвоєння нових знань, вмінь і компетенцій.

Сучасний стан філологічної освіти потребує розв'язання низки завдань: розвиток професійної компетентності студентів-філологів; загальний розвиток філологічної культури майбугніх фахівців; корегування змісту професійної підготовки студентів філологічного факультету через впровадження унавчальний процес матеріалів, що готують студентів до складання міжнародних іспитів; інтенсифікація і оптимізація процесу навчання студентів-філологів на основі використання медіаосвітніх технологій. 


\section{МЕДІАОСВІТНІТЕХНОЛОГІЇ ЯК ЗАСІБ ФОРМУВАННЯ АНГЛОМОВНОӤ КОМУНІКАТИВНОӤ КОМПЕТЕНТНОСТІСТУДЕНТІВ-ФІЛОЛОГІВ}

Перехід до компетентнісного підходу в освіті не може відбуватися без урахування іiї широкої інформатизації у суспільстві. Про сутність цих процесів йдеться у роботах С. Абрамова, Н. Апатової, О. Вербицького, Д. Белла, Г. Канна і О. Тоффлера. Відповідно до досліджень відомого британського психолога Дж. Равена, компетентність $\epsilon$ специфічною здатністю, необхідною для ефективного виконання конкретної дії в конкретній предметній галузі, в іiї складі вчений визначає вузькоспеціальні знання, предметні навички, способи мислення, а також розуміння відповідальності за свої дії. У структурі компетентності науковець виділяє такі складові: когнітивну, афективну, вольову, навички і досвід [7].

У В. Маслова ми знаходимо таке пояснення терміну: “готовність на професійному рівні виконувати свої обов' язки відповідно до світових вимог і стандартів, називається компетентністю" [3]. Компетентність також розглядається вченими як поєднання знань і здібностей, що дозволяє обгрунтовано судити про будь-яку сферу діяльності людини.

Ключовою метою навчання англійської мови сьогодні є навчання повноцінному спілкуванню 3 носіями мови i вмінню орієнтуватися в соціокультурному просторі. Для реалізації заданої мети і забезпечення позитивного соціальноекономічного розвитку суспільства потрібні відповідні технології. На сучасному етапі розвитку суспільства інформація і наукові знання доповнюють один одне в їхньому функціональному забезпеченні суспільного прогресу як нового продукту економіки. Саме тому медіа освітні технології виходять на перший план в сучасних освітніх реаліях [4].

В цілому, термін "медіаосвіта" вперше було вжито у документах ЮНЕСКО у 1973 році та розтлумачено як навчання теорії та практичних умінь для опанування сучасних мас-медіа, що розглядаються як частина специфічної, автономної галузі знань у педагогічній теорії та практиці [5].

Цінність використання медіазасобів на заняттях англійської мови полягає в їх універсальності та унікальності. Універсальність відображається в можливостях підвищення якості іншомовної комунікативної компетентності; візуалізації явищ, процесів, подій тощо; формуванні культурологічних знань студентів; формуванні уваги, пам'яті, естетичного смаку; розвитку логічного, образного та творчого мислення; розширенні світогляду. Унікальність медіазасобів на заняттях з основної іноземної мови знаходить свій прояв у можливостях вищезазначених засобів надавати доступ до аутентичних медіатекстів (анімаційних фільмів, кінофільмів, телевізійних програм, відеороликів, малюнків, графіків, фотографій, матеріалів сайтів тощо); розвивати критичне мислення; формувати навички самостійної роботи; залучати до інтерактивного навчання; розвивати творчі здібності [6].

Можливості використання технологій медіаосвіти уметодиці викладання іноземних мов та комп'ютерного супроводу навчального процесу на сьогодні вражаючі, адже вони створюють умови для здобуття будь-якої необхідної студентам та викладачам інформації, а це дозволяє внести кардинально нове у звичайні форми роботи, сприяє цікавому і повнішому розкриттю навіть дуже складного матеріалу, і тим самим сприяє значному скороченню навчального часу для успішного засвоєння теми. Медіаосвітні технології можна використовувати на всіх етапах заняття, у самостійній роботі студентів, розробленні творчих проектів, підготовці до різноманітних тестувань або олімпіад.

Зауважимо, що модель навчання 3 використанням технологій медіаосвіти передбачає, що в центрі навчання - студенти, які досить активно залучаються до навчального процесу, сутність навчання - навчити самостійно здобувати необхідні знання, розвивати свої уміння та навички, в основі навчальної діяльності співпраця викладача та студента.

Відзначимо, що творчі викладачі, які крокують у ногу з часом прагнуть до використання у вишах медіаосвітніх технологій на своїх заняттях 3 англійської мови, але трапляються випадки, коли педагоги не спроможні використовувати їх за різних причин, саме тому процес формування англомовної комунікативної компетентності має здійснюватися поступово і планомірно. На думку Ю. Горвіц, той, хто вміє ефективно використовувати технології та інформацію - має новий тип мислення, i, відповідно, на новому рівні оцінює проблеми, 3 якими стикається в професійній діяльності [1,26].

Таким чином, виникає проблема вибору викладачем оптимального способу організації і забезпечення інформаційної підтримки власної дисципліни і розумного використання засобів IКТ у навчальній роботі зі студентами. Наразі реалізації завдань іншомовної освіти, значно сприяють сучасні медіа технології, зокрема, хмарні технології (англ. cloud computing or cloudbased learning), які набувають все більшої популярності. Їхнє використання стає неминучим, тому що ці технології створюють такий 


\section{МЕДІАОСВІТНІ ТЕХНОЛОГІІ ЯК ЗАСІБ ФОРМУВАННЯ АНГЛОМОВНОӤ КОМУНІКАТИВНОӤ КОМПЕТЕНТНОСТІСТУДЕНТІВ-ФІЛОЛОГІВ}

навчальний простір, який дозволяє тим, хто вивчає англійську мову зануритися в атмосферу цільової мови більше аніж будь-який інший навчальний простір [2].

Сутність хмарних технологій полягає у наданні можливості користувачам віддаленого доступу до послуг і додатків через Інтернет. Розвиток цієї сфери зумовлений потребою у програмному забезпеченні, яким можна керувати зсередини. Іншими словами для пересічного користувача створюється інформаційний простір-хмара, в якій можна створювати, зберігати, накопичувати, опрацьовувати різні документи.

Одним $з$ прикладів використання хмарної технології є створення викладачами власного класу на безкоштовному веб-сервісі Google Classroom. Цей сервіс був створений для навчальних закладів для того, щоб спростити процедуру створення, розповсюдження і класифікації завдань без паперовим шляхом. Викладач може користуватися сервісом Google Classroom, в якому об'єднані Google Drive, Google docs, Sheets and Slides.

3 досвіду роботи зі студентами-філологами, які опановують англійську мову як спеціалізацію можемо відзначити, що ефективність формування їхньої англомовної комунікативної компетентності залежить від того, яким чином відбуваються практичні заняття 3 англійської мови безпосередньо з самими студентами, оскільки навчання на власному прикладі має найбільший вплив на становлення складових професійної компетентності.

Отже, схарактеризуємо основні етапи роботи. Вважаємо, що роботу з формування англомовної комунікативної компетентності засобами хмарної технології у вигляді Google classroom можна умовно поділити на такі етапи. Етап підготовчий, під час якого викладач організовує студентів, реєструє їх в електронному класі, створює медіатеку корисних для курсу “Основна іноземна мова” матеріалів та пояснює сутність роботи у класі.

Етап другий - основний - етап, під час якого студенти виконують завдання з дисципліни, обмінюються файлами, спільно виконують проекти он-лайн, здійснюють комунікацію в усній та писемній формі. Наведемо основні форми роботи із залученням медіа освітніх технологій до процесу формування англомовної комунікативної компетентності студентівфілологів. Так, яскравим прикладом роботи на цьому етапі можуть стати творчі завдання, які студенти мають виконувати самостійно та потім завантажувати в електронний клас. Викладач лише спрямовує студентів на обмін інформацією через віртуальний диск. Різновидом роботи може стати створення теки загального доступу під назвою "Віртуальна майстерня професіонала" у групі, для архіву корисної інформації із відкритим доступом для всієї групи, яку кожний учасник може доповнювати. На цьому етапі студентифілологи активно залучаються до створення презентацій в програмах Power Point або через веб-сервіс Prezi.com, за допомогою якого вони мають можливість навчитися створювати мультимедійні презентації 3 нелінійною структурою. Корисним видом роботи 3 формування комунікативної компетентності студентів-філологів стає робота 3 побудови інтелект карт на основі таких програм: Coggle, Xmind, Freemind, BubbleUs, Mapul тощо. Під час такої роботи студенти не тільки вчаться складати карти, а й розвивають мовленнєві навички, а саме говоріння, оскільки за допомогою таких карт студенти легко вчаться створювати наочні опори того, про що говоритимуть за обраною темою.

Викладач, який має на меті підвищити ефективність формування комунікативної компетентності студентів в групі має залучати до роботи у класі додаткові електронні ресурси. Завдяки додатковим інтерактивним курсам, оснащеними аудіо, відео матеріалами 3 відповідною тематикою студенти швидше та більш ефективно формують власні мовленнєві навички. 3 досвіду роботи, можемо сказати, що такі підручники як: “Headway”, “Gateway”, "English File" та "Upstream" мають розроблені електронні додатки, використання яких значно полегшує роботу з підвищення загального рівня комунікативної компетентності студентівфілологів. Такими додатками $є$ I-Checker, який допомагає здійснювати як поточне, так i підсумкове оцінювання навчальних досягнень студентів, I-Tutor, дозволяє закріпити і повторити матеріал самостійно, окрім того, цей ресурс має значну кількість відео матеріалів із вже розробленими завданнями тестами, які допомагають вдосконалити аудитивні навички студентів. Окрім, розроблених інтерактивних курсів, зазначені НМК мають посилання на сайти, де студенти мають можливість самостійно підвищувати власний рівень англійської.

I, врешті, третій етап - заключний, підведення підсумків. Викладач надає шаблон електронного порт фоліо, який студент має заповнити, відповідно до того матеріалу, який він вивчив. Також можна заохочувати студентів до спільного проекту, де студенти на відстані працюють $з$ одним і тим самим документом i, де кожний учасник проекту 


\section{МЕДІАОСВІТНІТЕХНОЛОГІІ ЯК ЗАСІБ ФОРМУВАННЯ АНГЛОМОВНОЇ КОМУНІКАТИВНОЇ КОМПЕТЕНТНОСТІСТУДЕНТІВ-ФІЛОЛОГІВ}

може внести свої ідеї до обговорення Цікавими формами роботи з віртуальним диском можуть стати спільне рецензування або переклад запропонованого викладачем тексту, а також взаємне оцінювання писемних робіт (peer-to-peer review). Різновидом роботи на цьому етапі можуть стати завдання спрямовані на отримання відгуку і різному форматі для підтримки зворотного зв'язку із студентами та удосконалення курсу “Основна іноземна мова". Викладач має можливість оцінювати роботу кожного зареєстрованого студента, відстежувати прогрес, а після оцінки його роботи, він може повернути ії разом з коментарями.

Отже, беручи до уваги основні принципи роботи з медіаосвітніми технологіями, виникає питання про причини інтересу викладачів до цих хмарних технологій. На наш погляд, причин існує декілька: популярність - студенти швидко прилаштовуються до знайомих форматів роботи; простота роботи; доступність - якщо є доступ до Інтернет, завжди можна здобути доступ до Google Docs або Blogger.com тощо; безкоштовність; інтерактивність - ці технології дозволяють створити взаємодію між всіма учасниками освітнього процесу; взаємодоповнюваність: хмарні технології пронизують всі сфери навчального процесу і використовуються як на заняттях з англійської мови так і у позакласних видах діяльності таких як: керована самостійна робота і контрольна-самостійна робота; наочність: завдяки цьому сервісу і студенти, i викладач здобувають миттєвий доступ до результатів як сумісної так і індивідуальної роботи; відсугність меж: з одного боку хмарні технології не потребують наявності гаджетів постійно підключених до Інтернет, з іншого - спільна робота 3 проекту, постановка або виконання завдання стають можливими навіть якщо студент знаходиться вдома i не має спеціальних налаштованих програм.

Окрім того, впровадження хмарних технологій у процес навчання іноземних мов сприяє розв'язанню таких лінгводидактичних завдань: підвищення мотивації вивчення мови, розвиток здібностей і готовності до самостійного вивчення мови; підвищення активності студентів у процесі вивчення мови; активізація навчально-пізнавальної діяльності студентів; індивідуалізація навчання та реалізація особистісного підходу; інтерактивність навчання; інформатизація навчального процесу (доступ до різних джерел інформації); інтенсифікація навчання; моніторинг навчального процесу; формування елементів глобального мислення; збільшення обсягу лінгвістичних $\mathrm{i}$ культурологічних знань; формування та розвиток умінь і навичок у чотирьох видах мовленнєвої діяльності (читанні, говорінні, аудіюванні та письмі); розвиток умінь та навичок міжмовної, міжкультурної комунікації засобами медіа на основі поваги, взаєморозуміння, толерантності до культурних відмінностей і подолання бар'єрів; розвиток критичного мислення завдяки багатосуб'єктності в процесі сприйняття медіатексту: можливість виявити точки зору автора, порівняти протилежні позиції та сформувати власне судження; підвищення ефективності засвоєння студентами навчального матеріалу; спонукання до творчої діяльності.

Безперечним є той факт, що необхідною умовою реалізації формування англомовної комунікативної компетентності студентівфілологів є забезпечення послідовності дій на кожному етапі навчання. У підготовці філологів зі спеціалізацією англійської мови слід враховувати цільовий компонент, який посідає особливе місце в методичній системі вивчення англійської мови. Студент має чітко усвідомлювати завдання навчання англійської мови, які продиктовані запитами сучасного інформаційного суспільства.

Висновки. Таким чином, повноцінне формування англомовної комунікативної компетентності студентів-філологів в сучасному інформаційному суспільстві неможливе без залучення медіаосвітніх технологій до процесу навчання. Неможнапереоцінювати лінгводидактивний потенціал електроного класу. Безсумнівно, використання хмарної технології Google classroom має бути коректним, виправданим і доцільним. Передачу інформації - ще неможна вважати гарантією передачі знань і формування компетенцій у студентів у повному обсязі, тому сучасні медіаосвітні технології $\epsilon$ лише допоміжними засобами навчання, хоча й досить ефективними та продуктивними.

\section{ЛIТЕРАТУРА}

1. Горвиц Ю. М., Чайнова А.А., Подъяков Н.Н. Новые информационные технологии в дошкольном образовании. Москва, 1998. 328 с.

2. Логинова А. В. Преимущества использования приложения Google Docs в обучении иностранному языку. Молодой ученый. 2015. №8. С. 976-979. URL https://moluch.ru/archive/88/17423/ (дата обращения: 16.01.2019).

3. Маслов В. И. Стратегическое управление персоналом в условиях эффективной организации культуры. Москва, 2004. 288 с.

4. Овчарук О. В. Компетентності як ключ до формування змісту освіти. Стратегія реформування освіти України. Київ, 2003. 295 с .

5. Педагогічний словник / за ред. М.Д. Ярмаченка. Київ, 2001.363 с. 
6. Петрик Л. Методичні можливості застосування медіазасобів на уроках іноземних мов. URL: https:// library.udpu.edu.ua/library files/probl sych vchutela/ 2014/10_2/8.pdf.

7. Равен Дж. Компетентность в современном обществе. Москва, 2002. 218 с.

\section{REFERENCES}

1. Horwitz, Yu.M., Chaynova, A.A. \& Podiakov, N.N. (1998). Novye informacionnye tehnologii v doshkolnom obrazovanii [New information technologies in preschool education]. Moscow, 328p. [in Russian].

2. Loginova, A.V. (2015). Preimushchstva ispolzovaniya prilozheniya Google Docs v obuchenii inostranimu yazyku [Benefits in using Google Docs application in teaching foreign languages]. Junior scientist. No.8, pp. 976-979. Available at: https://moluch.ru/archive/88/17423 [in Russian].

3. Maslov, V.I. (2004). Strategicheskoe upravlenie personalom $v$ uslovijah jeffektivnoj organizacii kultury [Strategic personnel management in the conditions of effective organization of culture]. Moscow, 288p. [in Russian].

4. Ovcharuk, O.V. (2003). Kompetentnosti jak kljuch do formuvannja zmistu osviti [Competence as the key to the formation of the content of education]. Strategy of reforming education in Ukraine. Kyiv, 295p. [in Ukrainian].

5. Pedagogichnyi Slovnyk (2001). [Pedagogical dictionary]. (Ed.). Yarmachenko. Kyiv, 363 p. [in Ukrainian]. 6. Petryk, L.V. Metodychni mozhlyvosti zastosuvannya mediazasobiv na urokah inozemnyh mov [Methodological opportunities for using media during English classes]. Available at: https://library.udpu.edu.ua/library files/ probl sych vchutela/2014/10 2/8.pdf. [in Ukrainian].

7. Raven, J. (2002). Kompetentnost $v$ sovremennom obshhestve [Competence in Modern Society]. Moscow, 218 p. [in Russian].

Стаття надійшла до редакції 07.06.2019

УДК 373.5.013:316.614.3./5

DOI:

Василь Кизенко, кандидат педагогічних наук, провідний науковий співробітник відділу дидактики Інституту педагогіки НАПН України

\section{ФЕНОМЕН СОЦАЛЬНОЇ СФЕРИ ЯК ДЕТЕРМІНАНТА ПРОЦЕСУ ФОРМУВАННЯ І РЕАЛІЗАЦІЇ ЗМІСТУ КУРСІВ ЗА ВИБОРОМ ДЛЯ УЧНІВ СТАРШОЇ ШКОЛИ}

Актуальність порушеної проблеми трунтується на ідеях, меті, організації процесу навчання і виховання, особливостях профілізації сучасної старшої школи і феномені суспільства як мірила якості життєдіяльності особистості. 3 урахуванням тенденцій розвитку теорії змісту шкільної освіти теоретично обтрунтовується зміст курсів за вибором, акцентується аксіологічний аспект професійного становлення, суб 'єктного досвіду особистості учня старшої школи у сочіально-педагогічній системі.

Ключові слова: старша школа; профільне навчання; курси за вибором; соціалізація особистості. Jim. 14.

Vasyl Kyzenko, Ph.D.(Pedagogy), Leading Researcher of the Didactics Department, Institute of Pedagogy of NAPS of Ukraine

\section{PHENOMENON OF THE SOCIAL SPHERE AS DETERMINANT OF THE PROCESS OF FORMATION AND REALIZATION OFTHE CONTENT OF ELECTIVE COURSES FOR UPPER SECONDARY SCHOOL PUPILS}

The urgency of the problem is based on the ideas, goals, organization of the process of education and upbringing, on the features of profiling of modern upper secondary school and on the phenomenon of society as an indicator of the quality of vital activity of the individual. The author is theoretically substantiating the content of elective courses, noting that it is necessary to take into account the trends in the development of the theory of the content of school education. He believes that the axiological aspect of the content of elective courses influences the professional formation, the subjective experience of the personality of upper secondary school pupil in the system of social and pedagogical relations.

In the content of profile education, it is important to actualize the perspective needs of society, to motivate the educational needs of children, and to teach correlation of these inquiries with the requirements of production spheres or individual production, as well as the needs stemming from social relations. Social, pedagogical and content components directly affect the management activities of institutions of general secondary education. Management, respectively, must be understood as a complex spiritual and social phenomenon of human life, as a distinct cognitive system.

Clarification requires the theoretical and methodological approaches to the development of all aspects of subject preparation of pupils within the limits of the invariant and variable educational components. The profilization 